\title{
MODERN MANAGEMENT TECHNOLOGIES IN THE HOSPITALITY INDUSTRY
}

\author{
Olena Sukach ${ }^{1}$, Svitlana Kozlovska², Natalia Sushko³
}

\begin{abstract}
The hospitality industry is currently one of the dynamic areas of the developing economy which stimulates the development of various sectors of the modern economy. The current challenges posed by the next economic crisis and the effects of pandemic constraints require the formation of new mechanisms for managing the hospitality sector. The main purpose of the research is to create modern management tools for the development of the investment potential of the hospitality industry. The subject of the research includes Ukrainian hospitality enterprises, their financial condition and management in a pandemic. The process of systematization of literary sources has identified the main modern problems of the hospitality industry, which include hotels, restaurants, entertainment, sporting events, and other services related to tourism. However, this specific area has a unique set of problematic aspects that need to be solved immediately. Understanding the importance of the management system in the hospitality industry and its adaptation to modern changes will help increase the competitiveness of such enterprises in the market. Research methodology: the article uses the funds of empirical studies of the essence of the hospitality industry, as well as statistical analysis of the modern market of hotel services. Also, the investment market in the sector of tourism was studied with the help of mathematical tools. Modern management in the hospitality industry is aimed at deviating from the typical and traditional tools to meet customer needs, which is caused not only by social change but also by the development of various financial instruments. The study proves that the successful development of the hospitality industry is impossible without the use of modern management tools based on the principles of marketing. Analyzing the market of hospitality services, in the process of development and implementation of innovative services, it is advisable to focus on the study of a competitive environment and the needs of potential customers. Conclusions. The results of the study prove the importance of this area and the feasibility of developing and implementing effective management tools. The research substantiates and offers promising areas for attracting investment resources in the hospitality industry. Also, according to the results of the study, the authors propose the stages of implementation of target marketing as an effective tool for the development of hospitality in Ukraine. The concept of development of innovative services in the field of hospitality on the basis of the formed strategy of target marketing is developed.
\end{abstract}

Key words: hospitality industry, hotel business, financial instruments, investments, hospitality enterprises, the concept of development of innovative services.

JEL Classification: E22, M11, M31, L26, L53

\section{Introduction}

The hospitality industry is currently one of the dynamic areas of the developing economy which stimulates the development of various sectors of the modern economy. The current challenges posed by the next economic crisis and the effects of pandemic

\footnotetext{
Corresponding author:

${ }^{1}$ Rauf Ablyazov University East European, Ukraine.

E-mail: sukach.o.m@gmail.com

ORCID: https://orcid.org/0000-0001-7150-0262

ResearcherID: E-7418-2019

${ }^{2}$ Rauf Ablyazov University East European, Ukraine.

E-mail: ksv750704@gmail.com

ORCID: https://orcid.org/0000-0002-1754-1220

${ }^{3}$ Rauf Ablyazov University East European, Ukraine.

E-mail: natalia sushko@ukr.net

ORCID: https://orcid.org/0000-0003-2201-0755
}

constraints require the formation of new mechanisms for managing the hospitality industry.

At the current stage of social transformation, the hotel business is in a difficult situation, which is associated with significant competition in the market and the effects of the global financial crisis. In 2017 in Ukraine, 
the number of hotels and similar accommodations was 4432 units, in particular: 3392 units were represented by private enterprises (Statistical collection, 2018). In 2018, the number of accommodations raised to 4985 units (Statistics, 2020). This situation forces hotel owners to develop and implement various measures that will allow them not only to stay afloat but also to take a leading position in this market. It is the uncertain state of the hotel business market in our country that requires hospitality entities to actively improve and implement the provisions of management policy aimed at ensuring the development and obtaining the necessary income.

As the most important function of the hospitality industry, management activity in the hotel business should ensure constant, stable, competitive operation and development of the management system in the market of hotel services taking into account the internal and external environment of the enterprise. The basis of such activities is a marketing approach, which, in turn, involves the implementation of comprehensive marketing research, and the creation, based on them, strategies and software measures to ensure the economic efficiency of the hotel business and increase the level of meeting needs of the end user.

Currently, there are a number of problems in the hospitality industry in Ukraine that need careful research and solution. In particular, it is necessary to: study the development trends of the hotel business, modern trends in the policy of promoting the hotel product on the market; evaluate the effectiveness of financial instruments for the promotion of hotel services; to generalize the existing experience of marketing policy implementation in the hotel business, as well as to form the maximum set of tools for financing the development of the hospitality industry.

\section{Literature review}

Despite the considerable interest in the stages of development of the hospitality industry, the issues of the ultimate satisfaction of the needs of citizens in high-quality hotel services remain unresolved now. So, the results of research on the development of the hotel business are presented in the papers of a significant number of authors. For example, V. Fedorchenko believes that human resources (skilled workers) are those important resources that underpin the hospitality industry (Fedorchenko, 2003). The economic aspects of the development of the hotel industry were studied by H. Krul, T. Tleuberdinova, D. Ussenova, O. Yurchenko, etc. Problems of marketing research are presented in the works by foreign scientists, such as T. Ambler, J. Evans, P. Kotler, J.-J. Lambin, etc. Many foreign scientists agree that the hospitality industry is a joint activity of the service sector to meet the needs of vacationers.
In common sense, the term "hospitality" is defined as respect for the guest, but the economic meaning of this definition is more complex; in this regard, experts have some differences in understanding the content of the hospitality industry. According to J. Walker, the hospitality industry combines tourism, hotel and restaurant business, catering, recreation and entertainment, conference and meeting organization (Walker John, 2017). According to dictionary Merriam-Webster, "the hospitality industry is a sphere of entrepreneurship consisting of such services based on the principles of hospitality, characterized by the friendly or courteous treatment of guests" (Webster). Many foreign researchers agree that the hospitality industry is a joint activity of different fields operating to achieve a purpose to meet the different needs of tourists.

Consequently, the hospitality industry is an organizationally significant, more complex area of activity that focuses on meeting the demand of not only tourists who actually travel but also of customers living in local lodging enterprises (Malskay, Pandyak, 2012).

E. Zin noted that the "hospitality industry" is a part of the social infrastructure of the region, which creates favorable conditions for the movement and development of the population (Zin, 2007). "Hotel business" means the activity that offers its own services and benefits that provide the necessary physical living conditions for tourists. This is how Marcel Gauthier explains the essence of the hotel industry. He also adds that this applies to services that tourists need during their business or family trips outside their permanent residence (Zin, 2007).

Among Ukrainian researchers, Z. Tymoshenko, H. Munin, L. Strashinska, Yu. Kariahin, T. Demura, etc. have conducted research on the basic principles of hospitality marketing. However, despite the significant developments and results of the study, the use of financial instruments for the implementation of management and marketing policy in the hotel business remains open.

\section{Research results}

The hotel business is an integral part of the tourism industry. Acting as the foundation for the material and technical base of tourism, it allows us to create a positive tourist image and helps meet the needs of tourists.

The main factors in the formation and development of the hospitality industry are (Malskaya, Pandyak, 2012): - social development of public relations, which has led to demographic and migration processes, the availability of a network of hotels and other accommodation to implement them;

- economic increase in the individuals' incomes, the significant economic potential of some regions and centers; 
- features of a mindset, culture and religion that influence the formation of the hotel chain and determine the types of hotels;

- scientific and technological progress;

- development of recreational and tourist natural resources.

Nowadays, under the influence of globalization processes, the global hotel business is represented by four models of hospitality: American, European, Asian, and Eastern European. Features of the American model of international hotel business development are based on the concept of the hotel chain using the benefits of the brands' image as a marketing tool that promotes the hotel product in domestic and foreign markets.

The European approach aims to maximize the coverage of target segments. In addition, European companies in their activities attach particular importance to the national and cultural characteristics of the countries in which they work. This allows those companies to achieve significant success in the international hotel business. The Asian model is the most agile in developing the hotel business.

The Eastern European model of hospitality stands out from the European one due to the large share of postSoviet enterprises in the hotel industry, as well as the proximity of hotels typical of European countries and the Asian model, according to the American model.

In total, today there are about 402,900 hotels of various star ratings in the world. For example, approximately 204,100 "star" hotels have been opened in Europe; consequently, the total number of all accommodation establishments, including mini-hotels, hostels, and apartments, reaches 660,000. Most of the hotels with a star ratings are located in Italy $(32,803$ hotels), followed by hotels in Croatia (29,282 hotels), France, Germany, Great Britain, and Spain.

According to the estimations, in 2018, there were more than 600,000 tourist accommodation establishments in the EU-27, and together they provided almost 28.3 million sleeping accommodations (Table 1). More than a third $(36.1 \%)$ of all sleeping accommodations in the EU-27 were concentrated in only two EU member states, namely Italy and France
(5.1 million sleeping accommodations each), followed by Spain and Germany (3.6 and 3.5 million sleeping accommodations respectively).

As a rule, in recent years, the number of visits to tourist establishments in the EU tends to increase (Figure 1). After the financial and economic crisis in 2008 and 2009 , the number of nights began to recover in 2010 and reached a maximum of 2.8 billion nights in 2018 , which was $2.7 \%$ more than in 2017 (Tourism statistics, 2018). It is estimated that in 2019, residents spent 1.74 billion nights in tourist facilities in the European Union. That is, taking into account non-residents there were 1.68 billion people who stayed overnight in short-term housing in the same year. That is, taking into account non-residents there were 1.68 billion people who stayed overnight in the short-term accommodations in the same year. In total, overnight stays in all types of accommodation in the EU in 2019 reached approximately 3.42 billion nights.

When evaluating the distribution by type of accommodation, hotels and similar lodgings were clearly the most popular (64\%), followed by rented apartments $(23 \%)$ and campsites, recreation parks and trailers (13\%). However, there were significant regional differences, while in Denmark, Luxembourg, France, and Sweden the share of the camping market was more than twice the EU average (Tourism statistics, 2018).

All three types of tourist accommodation increased in 2018. The number of nights spent in hotels increased by $2.4 \%$. Nights spent on holidays and other shortterm accommodation and nights spent on campsites increased by $3.6 \%$ and $1.3 \%$, respectively.

As of January 1, 2020 (operational data from UKRSTAT), the number of dormitories and similar temporary accommodations in Ukraine was 4989 units. This number has increased significantly in recent years (Figure 2), which, accordingly, boosts the level of competition between them.

The main reason for this situation is the increase in tourist flow within Ukraine. Thus, according to the statistics department, the number of official tour operators in Ukraine in 2018 amounted to 1,833 units (+ 90 units compared to 2017). They

Table 1

Number of tourist accommodation facilities in the EU, 2018

\begin{tabular}{|l|c|c|c|}
\hline & Number of establishments (units) & $\begin{array}{c}\text { Number of sleeping accommodations } \\
\text { (thousands) }\end{array}$ & Nights spent (millions) \\
\hline EU-27 & 600,157 & 28,294 & $2,791.2$ \\
\hline Germany & 50,020 & 3,474 & 419.6 \\
\hline Spain & 51,418 & 3,600 & 466.9 \\
\hline France & 29,652 & 5,112 & 442.8 \\
\hline Italy & 216,141 & 5,113 & 428.8 \\
\hline United Kingdom & 84,580 & 3,944 & 354.4 \\
\hline Other countries & 168,346 & 7,052 & 679 \\
\hline
\end{tabular}

Source: Formed by the authors according to: https://ec.europa.eu/eurostat/statistics-explained/index.php?title=Tourism_statistics\#Bed_places_in_ the_EU-27:_Italy_and_France_predominate 
Vol. 7 No. 3, 2021

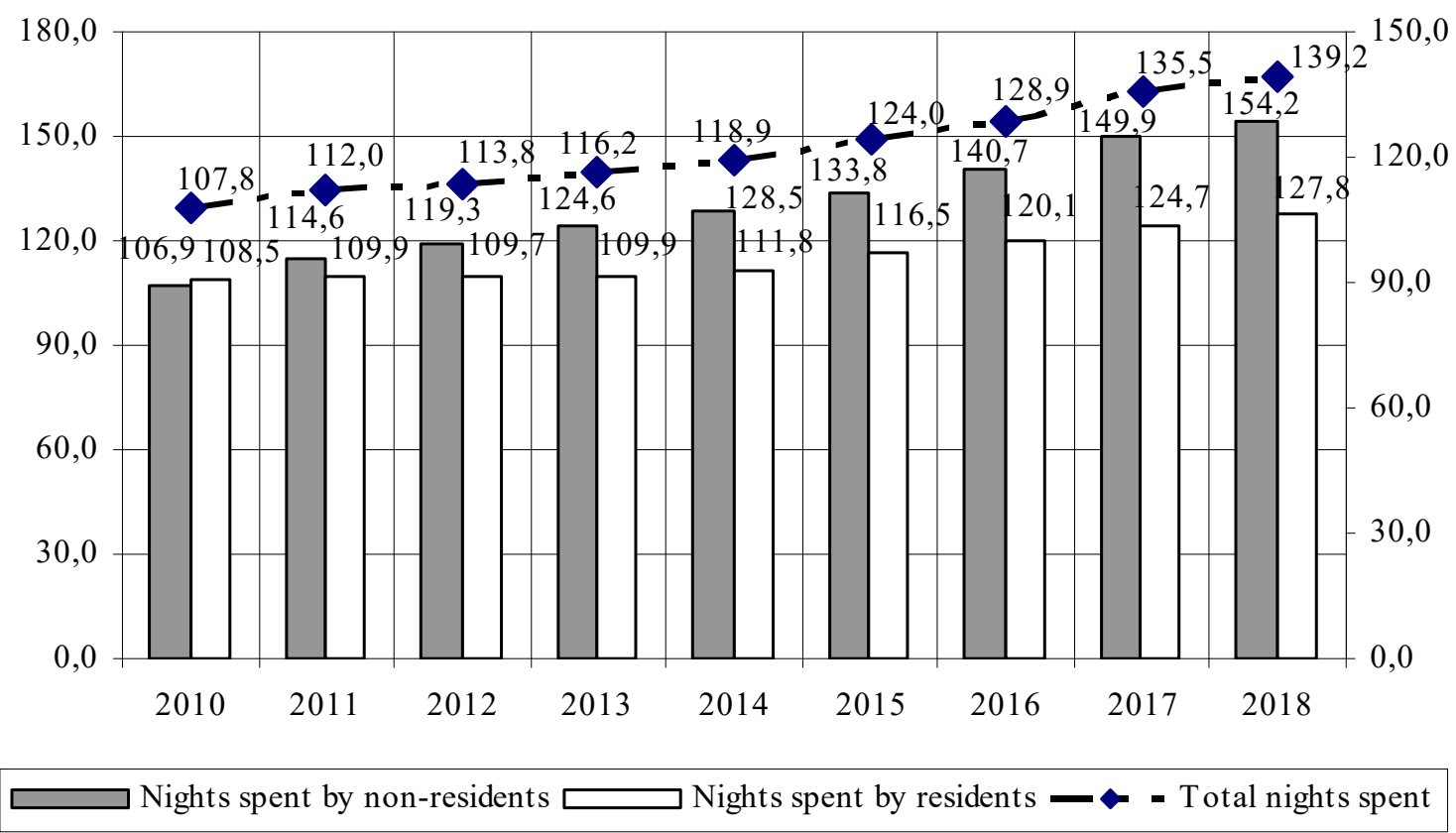

Figure 1. Trends in nights spent at EU-27 tourist accommodation establishments, EU-27, 2010-2018, \%

Source: Formed by the authors according to: https://ec.europa.eu/eurostat/statistics-explained/

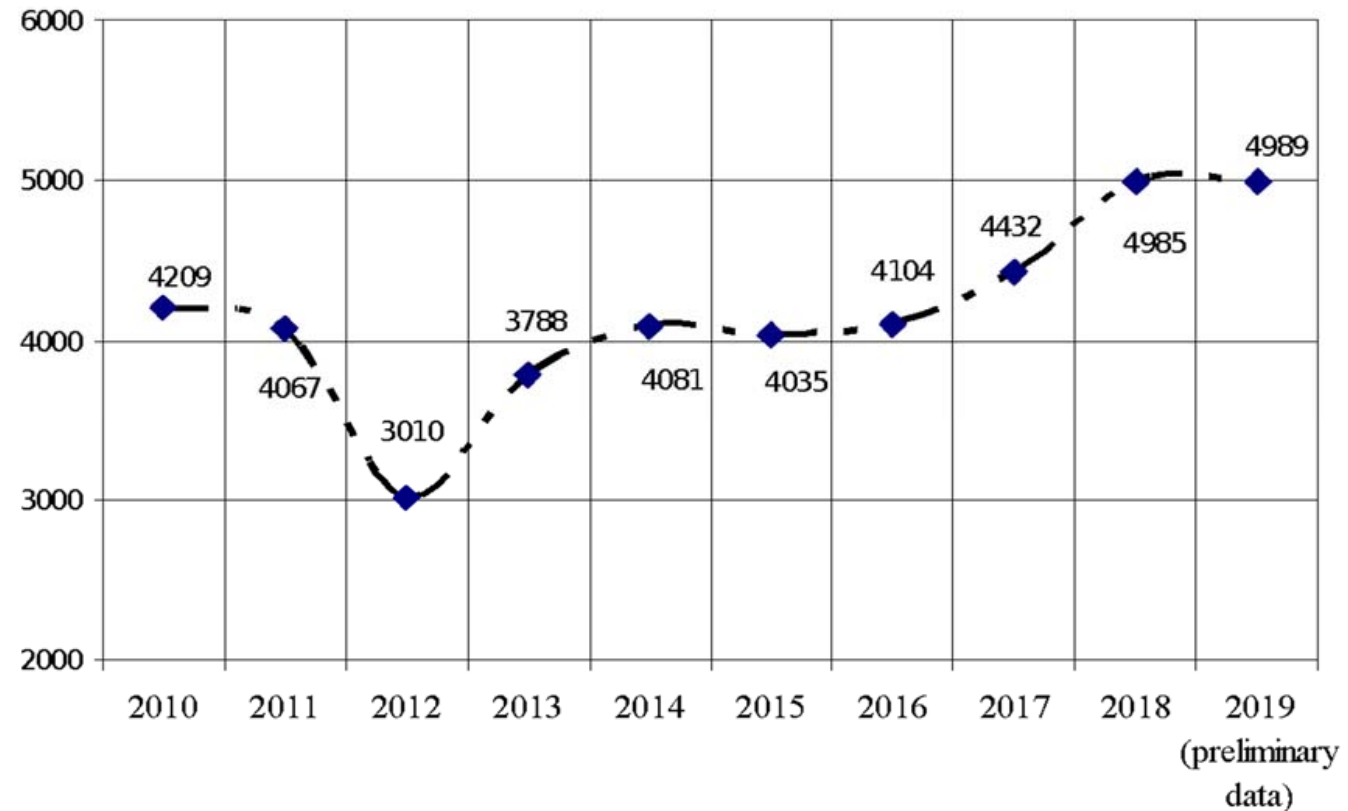

Figure 2. The number of accommodation facilities in Ukraine for 2010-2019, units

Source: Formed by the authors according to: http://www.ukrstat.gov.ua

served 4,481,502 domestic tourists $(+62 \%)$ and 75,945 foreigners (+92\%) in Ukraine.

There are also a number of "independent" tourists who also use the services of hotels and similar lodgings. Hotels and other places of temporary accommodation for tourists in Ukraine are mainly represented by small and medium businesses (Figure 3).

The vast majority of hotel business entities consist of small entrepreneurs. Accordingly and ambiguously, this is reflected in the results of their activity, namely the profit, seasonality of services, and inconsistencies in legislation.

In the EU, one in ten companies in the European nonfinancial economy belonged to the hospitality industry. These 2.4 million enterprises employed 13.6 million people. Hospitality enterprises accounted for $9.5 \%$ of those employed in the non-financial economy and $21.7 \%$ of those employed in services. The share of 

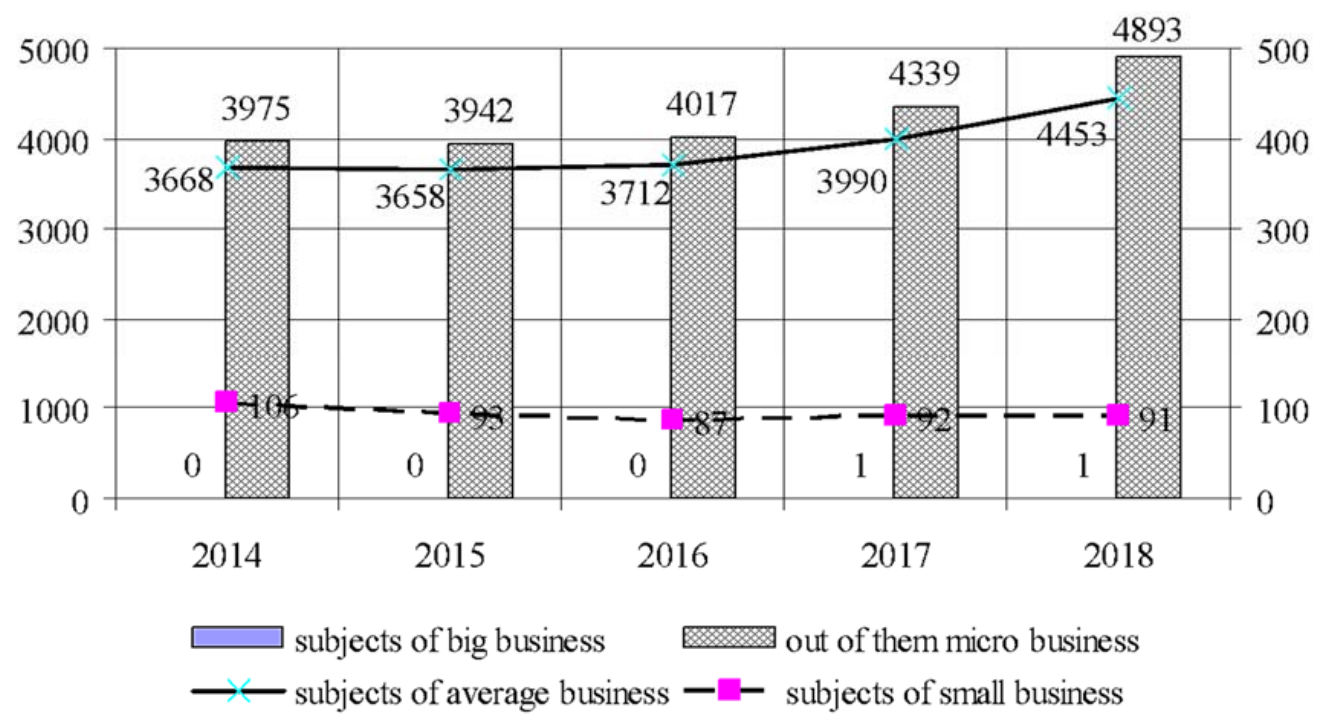

Figure 3. Distribution of hotels and similar placements by business entities, units

Source: Formed by the authors according to: http://www.ukrstat.gov.ua

hotel enterprises in total turnover and value added at actual value were relatively lower. Thus, the hospitality industry accounted for $3.9 \%$ of turnover and $5.8 \%$ of value added of the non-financial economy.

Hospitality has a double meaning: on the one hand, it is a friendly attitude to the guest, and on the other hand, it means a cooperative enterprise in various fields, aimed at making a profit by meeting customer needs. As we know now, only in 2017-2018 entrepreneurs of the hospitality industry were able to make a profit (Table 2).

The reason for this is the rather low purchasing power of citizens who choose more budget accommodation, as well as the "dubious" quality of services provided. Accordingly, increasing the number of "consumers" of hotel services contributes not only to increase the number of hotel enterprises but also to improve the quality of services provided under these conditions, the market policy of business participants becomes the basis for competitiveness of the hospitality industry.

Management decisions and the use of marketing technologies in the hospitality industry allow us to determine the guests' needs, create attractive conditions and offer the most comfortable services for basic market research, product planning, advertising and promotion. Modern marketing, which is often called integrated marketing, affects all sectors of any hotel business, its functional organizational structure.

Accordingly, the development of marketing strategies today is the foundation for the successful development of the hotel industry. As the main features that must be considered in the formation of marketing strategy, we can mention the following:

1. Demand for hotel services is extremely elastic in terms of income and prices, but it also largely depends on socio-economic conditions.

2. Due to seasonality in demand, there can be observed the so-called saturation phenomenon.

3. The offer of hotel services differs in its inflexible work practices. They can be consumed only in the places of their production; they cannot fully adapt to changes in consumers' demand over time and space.

4. Hotel product is developed by the efforts of many companies; each of them has its own methods of work, specific needs, and different business goals.

Table 2

The financial results of the activities of hotels and means of temporary accommodation of citizens in 2014-2018

\begin{tabular}{|c|c|c|c|c|c|c|}
\hline & \multirow{2}{*}{$\begin{array}{c}\text { financial result } \\
\text { (balance) before } \\
\text { tax, thousand UAH }\end{array}$} & \multirow{2}{*}{$\begin{array}{c}\text { net profit (loss), } \\
\text { thousand UAH }\end{array}$} & $\begin{array}{c}\text { \% to the total } \\
\text { number } \\
\text { of enterprises }\end{array}$ & $\begin{array}{c}\text { profit-making businesses } \\
\text { financial result, } \\
\text { thousand UAH }\end{array}$ & $\begin{array}{c}\text { \%to the total } \\
\text { number } \\
\text { of enterprises }\end{array}$ & $\begin{array}{c}\text { enterprises that received the loss } \\
\text { financial result, } \\
\text { thousand UAH }\end{array}$ \\
\hline 2014 & $-5,118,590.2$ & $-5,142,911.5$ & 47.7 & $170,797.8$ & 52.3 & $5,313,709.3$ \\
\hline 2015 & $-5,243,358.3$ & $-4,959,158.6$ & 56.7 & $317,428.5$ & 43.3 & $5,276,587.1$ \\
\hline 2016 & $-2,124,046.6$ & $-2,028,619.9$ & 59.0 & $803,661.3$ & 41.0 & $2,832,281.2$ \\
\hline 2017 & $1,463,132.0$ & $1,470,289.3$ & 59.0 & $2,963,395.4$ & 41.0 & $1,493,106.1$ \\
\hline 2018 & $2,158,170.2$ & $1,846,720.1$ & 63.8 & $2,697,681.8$ & 36.2 & $850,961.7$ \\
\hline
\end{tabular}

Source: Formed by the authors according to: http://www.ukrstat.gov.ua 


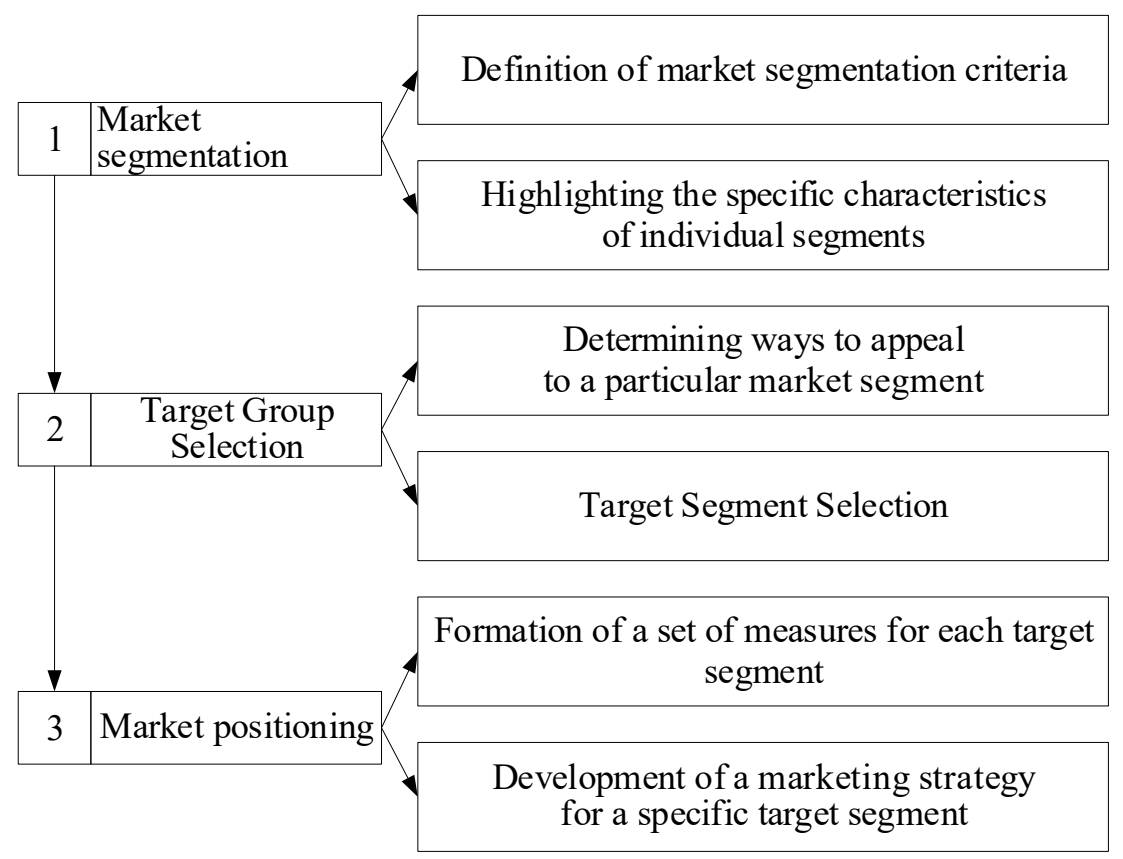

Figure 4. The stages of target marketing

Source: author development

5. High-quality hotel services cannot be achieved if there are even the slightest non-conformities because guest service consists of these smallest details.

In this regard, many hotel chains prefer target marketing to optimize market opportunities and develop appropriate products for each segment of the target market. Businesses can adapt their products, prices, distribution channels and advertising to maximize their outcome.

In general, target marketing in the hospitality industry consists of three main stages (Figure 4).

Thus, at the first stage the market of hotel services is segmented with the formation of groups of "consumers". The purpose of segmentation is to create favorable conditions for guests and reduce hotel costs.

Defining marketing opportunities creates a basis for detailing the target group. This approach allows businesses not to dissipate their efforts but to focus them on the most promising sectors. This ensures the concentration of financial, physical and labor resources and increases the efficiency of the forms and methods of marketing, advertising, sales promotion, etc. It is impossible to achieve this goal without choosing and implementing a well designed marketing strategy.

The choice of marketing strategy is based on the formation of marketing goals, development of alternative strategies, their justification and evaluation in accordance with the criteria of compliance with the goals, potential of the enterprise and the degree of risk in the sector of marketing. The practical implementation of marketing strategy is associated with the choice of the range of tools that ensure the materialization of goals and objectives.

When creating and promoting a new product, the analysis of the situation on the market of hotel services can reduce the risks of its commercialization. Among the important strategic objectives for the development of the hospitality industry, it is advisable to consider the diversification of offers, expansion of the range of hotel services.

The development of hotel chains facilitates the emergence of various forms of management, which, in turn, increases the efficiency of hotel management, as well as the inflow of investment in the hotel business directed from other sectors of economic activity.

The hospitality industry is based not only on customer satisfaction and employment in a particular market segment but also on profit.

As noted earlier, the financial results of the hospitality industry in 2017-2018 had positive results, and the profitability of operating activities was $22.3 \%$ (2018) (Statistical publication, 2018). The main reason for stabilizing the situation was the improvement of the quality of services, as well as significant investment in this industry.

Thus, according to statistics, in 2019 the volume of capital investments in the hospitality industry amounted to 968,753 thousand UAH (+6\%). In 2018, this figure increased by $3.3 \%$ to 934.6 million UAH. That is, annual investments in the hotel sector do not exceed 1 billion UAH. There are no exact statistics on the sources of financing of the hotel segment, but within the whole 
economy only $7.7 \%$ of capital investments were made through bank lending, and more than $70 \%$ belonged to companies and organizations (Capital investment, 2019). General investment activity in this area covers both tangible and intangible segments (Table 3 ).

The investments made it possible to solve a significant part of the problematic aspects of this business in 2013-2016 and raise the level of overall profitability in 2018 by $14.6 \%$. To one degree or another, the implementation of investment projects was accompanied by the introduction of certain innovative technologies for creating new services and methods of providing them. Therefore, along with advertising and brand promotion, the marketing strategic component in the hotel business is the implementation of certain innovative projects in the hospitality industry.

The hotel product is an important factor influencing the hospitality industry. In this regard, much attention is paid to the quality and further upgrading of the hotel product. Innovation in the hospitality industry is an important financial tool for competing in the hotel services market (Malskaya, Pandyak, 2012). The development of innovative services is carried out on the basis of monitoring innovative trends in the market, as well as analyzing the needs of potential consumers and the use of non-standard methods of solving strategic problems.

However, when deciding to diversify the range of hotel services, it is necessary to take into account possible threats, namely significant material costs at all stages: from the generation of the idea of creating a new hotel product to its final implementation.

We believe that the successful development of the hotel business is impossible without the use of integrated marketing. When analyzing the market of hotel services in the process of generating and creating innovative services, it is advisable to focus on studying the competitive environment and the needs of potential customers (Figure 5).

The concept of innovative services includes assessment of the impact of external and internal environment, definition of target segments, calculation of the sales forecast for hotel services. The possible sales forecast is the main result of the development of the marketing complex, the basis for financial analysis and determination of economic indicators of the project of implementation of innovative hotel services.

At the same time, the innovative development of the enterprise means not only the main innovation process but also the development of a system of factors and conditions necessary for its implementation, i.e., innovation potential.

One of the important points in the management of innovation in hotels is to determine (evaluate) the innovation performance. It is reasonable to group the main criteria for evaluating the results of innovation in the following areas:

- indicators that assess the production effect of the introduction of innovative hotel services;

- indicators that characterize the commercial gains of innovation;

- indicators that reflect the impact of investments made by hotel service providers in the commercialization of innovative hotel services.

Thus, in modern conditions, innovations and innovative activities are becoming increasingly important for economic development and successful financial activity of the hospitality industry, at the same time, being a foundation for the acquisition and occupation of leading positions in the market.

Table 3

Hospitality Capital Investments

\begin{tabular}{|c|c|c|c|c|c|c|c|c|c|}
\hline & & & & & Incluc & & & & \\
\hline & & & & & ut of them & & & Out of & hem \\
\hline & $\begin{array}{l}\text { Capital } \\
\text { investment } \\
\text { total }\end{array}$ & $\begin{array}{l}\text { Capital } \\
\text { investment } \\
\text { intangible } \\
\text { assets }\end{array}$ & In land & \begin{tabular}{|} 
In existing \\
buildings and \\
structures
\end{tabular} & $\begin{array}{l}\text { In construction } \\
\text { and reconstruction } \\
\text { of buildings }\end{array}$ & $\begin{array}{l}\text { In } \\
\text { machinery } \\
\text { and } \\
\text { equipment }\end{array}$ & $\begin{array}{c}\text { Capital } \\
\text { investment } \\
\text { in intangible } \\
\text { assets }\end{array}$ & $\begin{array}{c}\text { In } \\
\text { concessions, } \\
\text { patents, } \\
\text { licenses, } \\
\text { trademarks } \\
\text { and similar } \\
\text { rights }\end{array}$ & $\begin{array}{l}\text { In the } \\
\text { purchase } \\
\text { of software }\end{array}$ \\
\hline 2010 & $1,256,770$ & $1,250,502$ & 10,771 & 33,457 & 883,990 & 276,709 & 6,268 & 384 & 3,800 \\
\hline 2011 & $2,297,905$ & 229,0949 & 17,093 & 18,087 & $1,758,462$ & 381,058 & 6,956 & 667 & 5,887 \\
\hline 2012 & $1,456,543$ & $1,448,549$ & 19,694 & 17,311 & $1,152,764$ & 177,962 & 7,994 & 3,159 & 2,988 \\
\hline 2013 & 783,491 & 778,504 & 5,726 & 7,512 & 638,505 & 95,318 & 4,987 & 304 & 4,386 \\
\hline 2014 & 596,080 & 580,316 & 38,958 & 66,477 & 274,156 & 171,306 & 15,764 & 10,537 & 4,860 \\
\hline 2015 & 941,890 & 934,123 & 1,121 & 21,600 & 663,159 & 179,814 & 7,767 & 529 & 5,867 \\
\hline 2016 & $1,144,192$ & $1,129,869$ & 7,650 & 39,662 & 701,372 & 286,050 & 14,323 & 570 & 2,884 \\
\hline 2017 & $1,155,422$ & $1,140,634$ & 3,486 & 5,446 & 763,418 & 259,069 & 14,788 & 707 & 10,175 \\
\hline
\end{tabular}

Source: Formed by the authors according to: http://www.ukrstat.gov.ua 


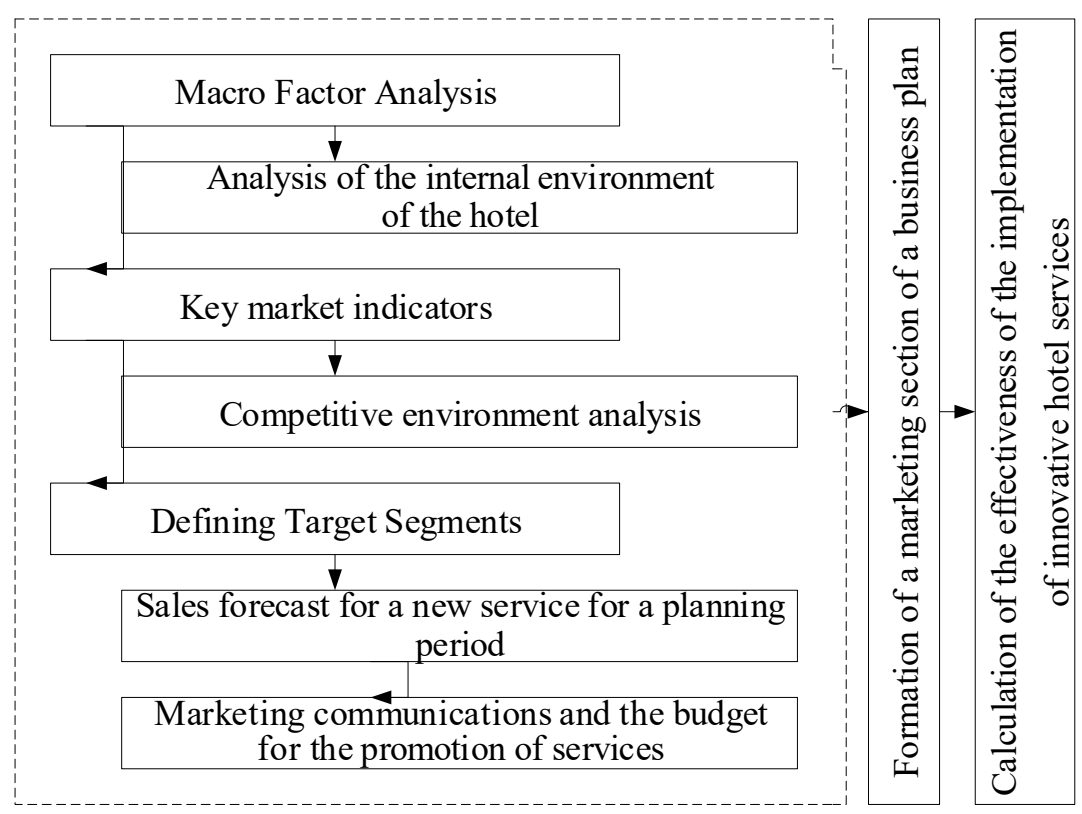

Figure 5. The concept of developing innovative services

Source: Author development

\section{Conclusions}

At the present stage of human development, the problem of hospitality helps solve the problems of migration and interstate hospitality.

Today, the hospitality industry is growing rapidly. Given modern technologies, market transformation trends, and the growing demand for hotel services, the role of marketing in conquering market segments should not be underestimated. The development and implementation of a marketing strategy to create and promote new services in the market is the basis of the modern hospitality industry.

However, given the cost of this sector of activity, effective financial investment tools cannot be avoided. However, when choosing a mechanism to attract investment, it is necessary to clearly understand their return and profitability. In this regard, it is advisable to direct investments only to promising activities, in particular to innovative projects because innovation affects economic development and successful financial and economic activities in the hotel industry.

Given the above, on the basis of the research carried out, the article substantiates the stages of development and implementation of targeted marketing in the hospitality industry.

Based on the proposed stages, the authors form the concept of the development and implementation of innovative services in the hospitality industry. Indicators for assessing the feasibility and effectiveness of investing financial resources in innovative services for profit are also summarized.

Thus, the hospitality industry is important not only for societies but also for the economy. Modern transformations and changes in the demand of consumers of hotel services in close connection with new technological and marketing solutions will allow for effective management and development of the hotel industry in the future.

\section{References:}

Collective placement in UKRAINE in 2017: Statistical collection (2018). Kyiv: State Statistics Service of Ukraine. State Statistics Service of Ukraine (2020). Available at: http:/ /www.ukrstat.gov.ua/

Fedorchenko, V. (2003). Theoretical bases of tourism personnel in Ukraine. Available at: http://www.ecologylife.ru/ tyrizm-2003/teoretichni-zasadi-kadrovogozabezpechennya-sferi-turizmu-v-ukrayini.html.

Krul, H. Ya. (2011). Basics of hotel business: tutorial. Kyiv: Center for Educational Literature.

Malskaya, M., \& Pandyak, I. (2012). Hotel business: theory and practice. 2nd ed. Kyiv: Center for Educational Literature.

Tleuberdinova, T., \& Ussenova, D. (2015). Theoretical foundation of formation and development of hospitality industry. Bulletin of Karaganda State Series of Economy, vol. 3(79).

Yurchenko, O. (2014), Innovations in hotel business at the modern stage. Bulletin of the Lviv University. Series international relations, vol. 34 . 
Walker, John R. (2017). Introduction to Hospitality (Subscription), 7th Edition. University of South Florida. Publisher: Prentice Hall.

Webster, M. English dictionary. Available at: https://www.merriam-webster.com/thesaurus/hospitality

Ambler, T. (2000). Marketing and the Bottom Line. The New Metrics of Corporate Wealth. London: Financial Times, Prentice Hall.

Evans, J. (2009). The Art of Self-Branding: Making Yourself Relevant to Employers. MBA Review (December). COVER STORY.

Kotler, P., \& Gertner, D. (2011). "A Place Marketing and Brand Management Perspective Revisited," in Nigel Morgan and Annette Prichard's Destination Brands: Managing Place Reputation, 3rd ed., Elsevier.

Lambin, J.-J. (2005) Menedzhment, oriientovanyi na rynok [Market-Driven Management], translated from English, edited by V.B. Kolchanova, Piter Kom, St.-Peterburg.

Tymoshenko, Z., Munin, H., \& Dyshlevyi, V. (2009). Marketynh hotelnoho produktu [Marketing of a hotel product]. Available at: www.tourism-book.com.

Marketynh hotelnoho i restorannoho hospodarstva produktu [Marketing of a hotel and catering product]. Kyiv: NUKhT.

Munin, H., \& Kariahin, Yu. (2008). Hotel and restaurant business management. Kyiv: Kondor.

Modern hospitality models. Available at: http://www.vfmgiu-tourism.ru/struktura_upravleniya_turizmom_39/ sovremennye_tendencii_razvitiya_industrii_gostepriimstva_364/sovremennye_modeli_gostepriimstva_368/ index.html

The total number of hotels in the world announced (2019). Hotel. report. Available at: https://hotel.report/events/ nazvano-obshhee-kolichestvo-otelej-v-mire

The official site of World Tourism Organization UNWTO (2020). Statistics of Tourism. Available at: http://www.unwto.org.

Activity of business entities: Statistical publication'2018 (2019). Kyiv: State Statistics Service of Ukraine.

Capital investment (2019). Available at: https://www.me.gov.ua/Documents/Detail?lang=uk-UA\&id=32a59dc2-

1c2b-4b80-868c-2062907bdeaf\&title=KapitalniInvestitsii-2019-Rik

Tourism industries (2018). Available at: https://ec.europa.eu/eurostat/statistics-explained 